PIPER, C. V. (1934). Cultivated grasses of secondary importance. U.S.D.A.Bull., 1433, pp. 1-42.

Piper, C. V., Vinall, H. N. \& Enlow, C. R. (1934). Important cultivated grasses. U.S.D.A. Bull, 1254, pp. 1-34.

PorTer, D. M. (1969). The genus Kallstroemia (Zygophyllaceae). Contr. Gray Herb., 198, pp. 41-153.

Porter, D. M. (1972). The genera of Zygophyllaceae in the southeastern United States. J. Arnold Arbor., 53, pp. 531-52.

RichaRDSON, D. R. (1976). Habitat and Successional Changes of the Atlantic Coastal Ridge of Palm Beach County, Florida. Unpublished M.S. thesis, Florida Atlantic University, Boca Raton, Florida: vii +138 pp., illustr. [available from the Library, Florida Atlantic University, Boca Raton, Florida 33431, U.S.A.].

RiPLEY, S. D. (1975). Report on Endangered and Threatened Plant Species of the United States. Smithsonian Institution, Washington, D.C.: House Document No. 94-51, iv + $200 \mathrm{pp}$.

Romans, B. (1775). A Concise Natural History of East and West Florida (Ed. R. W. Partick). Florida Facsimile Reprint Series, Gainesville, Florida, 1962: lii + 343 + Appendix of lxxiv pp.

RYERSON, K. A. (1967). The History of Plant Exploration and Introduction in the United States Department of Agriculture. (Proc. International Symposium on Plant Introduction at Tegucigalpa in 1966.) Escuela Agricola Panamericana, Apartado 93, Tegucigalpa, Honduras: pp. 1-19.

Small, J. K. (1902). Report... upon a trip to Florida. J. N.Y. Bot. Gard., 3, pp. 29-35.

SMALL, J. K. (1904). Report on exploration in tropical Florida. J. N.Y. Bot. Gard., 5, pp. 49-53.

SMALL, J. K. (1904). Report upon further exploration of southern Florida. J. N.Y. Bot. Gard., 5, pp. 157-64.

Small, J. K. (1905). Additions to the flora of subtropical Florida. Bull. N.Y. Bot. Gard., 3, pp. 419-40.

SmaLL, J. K. (1907). Exploration of southern Florida. J. N.Y. Bot. Gard., 8, pp. 23-8.

SMALL, J. K. (1909). Additions to the flora of peninsular Florida, I: Native species. Bull. Torrey Bot. Club, 36, pp. 159-64.

Small, J. K. (1909). Exploration in the Everglades. J. N.Y. Bot. Gard., 10, pp. 48-55.

SMALL, J. K. (1910). Additions to the flora of peninsular Florida, II: Naturalized species. Bull. Torrey Bot. Club, 37, pp. 513-8.

Small, J. K. (1911). Exploration in southern Florida. J. N.Y. Bot. Gard., 12, pp. 147-56.

Small, J. K. (1913). Report on exploration in tropical Florida. J. N.Y. Bot. Gard., 14, pp. 81-6.

Small, J. K. (1914). Exploration in the Everglades and on the Florida Keys. J. N.Y. Bot. Gard., 15, pp. 69-79.

Small, J. K. (1916). Exploration in southern Florida in 1915. J. N.Y. Bot. Gard., 17, pp. 37-45.
SMALL, J. K. (1917). Botanical exploration in southern Florida in 1916. J. N.Y. Bot. Gard., 18, pp. 98-111.

SMALL, J. K. (1918). A winter collecting trip in Florida. J. N.Y. Bot. Gard., 19, pp. 69-77.

SMaLl, J. K. (1919). Coastwise dunes and lagoons: a record of botanical exploration in Florida in the spring of 1918. J. N.Y. Bot. Gard., 20, pp. 191-207.

SMALL, J. K. (1920). Of grottoes and ancient dunes: a record of exploration in Florida in December 1918. J. N.Y. Bot. Gard., 21, pp. $25-8,45-54$.

Smale, J. K. (1921). Old trails and new discoveries. A record of exploration in Florida in the spring of 1919. J. N.Y. Bot. Gard., 22, pp. 49-64.

Small, J. K. (1922a). Another Sonchus for America. Torreya, 21, pp. 100, 101 .

SMALL, J. K. (1922b). The botanical fountain of youth. A record of exploration in Florida in April 1920. J. N.Y. Bot. Gard., 23, pp. 117-33, 139-55.

Small, J. K. (1923a). Historic trails, by land and by water. A record of exploration in Florida in December 1919. J. N.Y. Bot. Gard., 22, pp. 193-222.

SMALL, J. K. (1923b). Land of the question mark. Report on exploration in December 1920. J. N.Y. Bot. Gard., 24, pp. $1-23,25-43,62-70$.

SMALL, J. K. (1923c). Green deserts and dead gardens. A record of exploration in Florida in the spring of 1921. J. N.Y. Bot. Gard., 24, pp. 193-247.

SMALL, J. K. (1924). The land where spring meets autumn. A record of exploration in Florida in December 1921. J. N.Y. Bot. Gard., 25, pp. 53-94.

Small, J. K. (1926). Catharanthus roseus-Old maid. Addisonia, 11, pp. 27, 28.

Small, J. K. (1927). Among floral aborigines: A record of exploration in Florida in the winter of 1922. J. N.Y. Bot. Gard., 28, pp. 1-20, 25-40.

SMALL, J. K. (1933). Manual of the Southeastern Flora. University of North Carolina Press, Chapel Hill, North Carolina: xxii $+1,554$ pp., illustr.

SteInberG, B. (1976). Vegetation Analysis of the Atlantic Coastal Ridge of Broward County, Florida. Unpublished M.S. thesis, Florida Atlantic University, Boca Raton, Florida: vii +89 pp., illustr. [available from the Library, Florida Atlantic University, Boca Raton, Florida 33431, U.S.A.]

Weldon, L. W., Black buRn, R. D. \& Harrison, D. S. (1969). Common aquatic weeds. Agric. Handb. No. 352, pp. 1-43.

WhitTAKer, R. H. (1975). Communities and Ecosystems (edn 2). Macmillian, New York: xviii +385 pp., illustr.

Winberry, J. J. \& Jones, D. M. (1973). Rise and decline of the 'miracle vine': Kudzu in the southern landscape. Southeast. Geogr., 13, pp. 61-70.

\title{
Fears for Scimitar-horned Oryx
}

The Scimitar-horned Oryx (Oryx algazel) is gravely threatened with extinction within the next decade in Chad, where it has its last main refuge, according to a report received by the World Wildlife Fund. It is one of the few herbivores which can exist in the harsh climatic and vegetational conditions of the Sahelian and allied regions of Africa. There used to be enormous numbers of it; but in the past century-especially the last 30 yearspoaching, aided by motor vehicles and advanced weapons, and human activity in its traditional range, have reduced it to a few thousands. There are some 6,000 still in Chad, of which between $60 \%$ and $80 \%$ are in the vast Ouadi Rimé-Ouadi Achim Faunal Reserve. Between 1972 and 1976, intensive protection measures were enforced and, with reasonably good rains and pastoral conditions, the Oryx thrived.

In 1976 the rains failed, however, and shortage of fuel and spare parts, as well as the disturbed political situation, has seriously reduced anti-poaching patrols. In search of food the Scimitar-horned Oryx are moving into areas where they are more vulnerable than hitherto. As a result, any earlier population increase is being lost. Now a report to the World Wildlife Fund indicates that, unless poaching control can be restored to former levels, "the next five years will certainly see the Oryx population decline to such a degree that they [will] become non-viable as a selfsustaining reproductive group. From that stage, the end is not far away.'

The World Wildlife Fund has been providing funds for vehicles, patrol camels, guards' personal equipment, fuel, and spares, as part of the effort to save this Oryx, which could once again be a valuable source of meat and skins if their numbers were restored and properly managed.

PETER F. R. JACKSON, Director of Information World Wildlife Fund 1110 Morges, Switzerland. 